\title{
MODEL PERANGKAT PEMBELAJARAN MENULIS BERDASARKAN PENDEKATAN PROSES GENRE BAGI SISWA SMP
}

\author{
Kastam Syamsi \\ Fakultas Bahasa dan Seni Universitas Negeri Yogyakarta \\ e-mail: kastam@uny.ac.id
}

\begin{abstract}
Abstrak
Penelitian pengembangan ini bertujuan untuk menghasilkan model perangkat pembelajaran menulis berdasarkan pendekatan proses genre bagi siswa SMP. Prosedur penelitian ini mengikuti model R2D2 yang terdiri atas tiga tahap, yakni (1) pendefinisian, (2) perencanaan dan pengembangan, dan (3) penyebarluasan. Data penelitian mencakup data kualitatif dan kuantitatif. Data kualitatif dianalisis dengan teknik analisis domain dengan prinsip kritis dan reflektif, sedangkan data kuantitatif dianalisis dengan teknik analisis statistik uji-t dengan program SPSS 15.0 for Windows. Hasil penelitian ini terdiri atas lima model, yakni (1) silabus, (2) RPP, (3) buku ajar, (4) instrumen evaluasi, dan (5) panduan pembelajaran menulis berdasarkan pendekatan proses genre bagi siswa SMP/ MTs. Berdasarkan analisis data diketahui bahwa kelima model perangkat pembelajaran menulis itu terbukti efektif terhadap peningkatan kemampuan menulis siswa.
\end{abstract}

Kata kunci: perangkat pembelajaran menulis, pendekatan proses genre

\section{MODELS OF TEACHING KITS FOR WRITING BASED ON THE GENRE PROCESS APPROACH FOR JUNIOR HIGH SCHOOL STUDENTS}

\begin{abstract}
This research and development study aims to produce models of teaching kits for writing based on the genre process approach for junior high school students. The procedure employed the R2D2 model, consisting of three main stages, i.e. (1) definition, (2) design and development, and (3) dissemination. The data consisted of qualitative and quantitative data. The qualitative data were analyzed using the domain analysis technique with critical and reflective principles, while the quantitative data were analyzed using t-test with SPSS 16.0 for Windows. The study produces five models, i.e.: (1) a syllabus model, (2) a lesson plan model, (3) a learning materials model, (4) an evaluation instrument model, and (5) a teacher guide model of the teaching of writing. Based on the data analysis, the five models of teaching kits for writing are effective to improve the students' writing ability.
\end{abstract}

Keywords: teaching kits for writing, genre process approach

\section{PENDAHULUAN}

Menulis dipandang sebagai keterampilan berbahasa yang sangat penting yang harus dikuasai oleh siswa (Hyland, 2007). Dengan keterampilan menulis yang baik, seseorang dapat menyebarluaskan pemikiran, pandangan, pendapat, gagasan atau perasannya tentang berbagai hal secara produktif, menarik, dan mudah dipahami. Akan tetapi, keterampilan menulis merupakan keterampilan berbahasa yang paling sulit dikuasai karena menulis adalah proses kognitif yang sangat rumit (Sibarani, 2007).

Aktivitas menulis tidak dapat dilepaskan dari budaya baca-tulis (Barton, Hamilton, \& Ivanic, 2000). Budaya bacatulis (literasi) merupakan kebalikan dari 
budaya dengar-ucap (orasi) (Alwasilah, 2005). Orang yang berpendidikan biasa disebut literat karena mampu melakukan keduanya.

Kenyataan menunjukkan bahwa budaya baca-tulis masyarakat Indonesia masih kurang memuaskan (Putra, 2008). Kemampuan membaca dan menulis anakanak Indonesia berada pada peringkat paling bawah apabila dibandingkan dengan anak-anak Asia (Supriyoko, 2004). Penelitian yang dilakukan IEA Study of Reading Literacy (Elly, 1992) dan Progress in International Reading Literacy Study (PIRLS) (Baer, Baldi, Ayotte, \& Green, 2007) menyimpulkan bahwa kemampuan membaca anak-anak sekolah dasar di Indonesia masih sangat rendah.

Rendahnya budaya baca-tulis disebabkan oleh lemahnya sistem pembelajaran menulis di sekolah (Anshori, 2003). Kenyataan menunjukkan pembelajaran menulis kurang mendapatkan perhatian yang sewajarnya (Slamet, 2007). Pembelajaran menulis sebagai salah satu aspek dalam pembelajaran Bahasa Indonesia kurang ditangani dengan sungguh-sungguh. Pada umumnya siswa Indonesia tidak pernah mendapatkan materi bagaimana cara menulis yang benar (Anshori, 2003). Siswa dan guru biasanya lebih menekankan kegiatan pembelajaran terhadap penguasaan materi yang mengarah pada keberhasilan siswa dalam ujian akhir nasional. Padahal, belajar menulis merupakan seperangkat proses yang kompleks dan sulit sehingga memerlukan kerangka metodologi pembelajaran yang jelas pada semua tahapan pembelajaran (Knapp \& Watkins, 2005). Menurut Nunan (1999), keterampilan memproduksi tulisan yang koheren, lancar, dan luas, merupakan keterampilan yang paling sulit dipelajari di antara keterampilan berbahasa. Dengan demikian, sudah semestinya pembelajaran menulis di sekolah mendapatkan perhatian yang memadai.

Menulis adalah suatu kegiatan penyampaian pesan dengan menggunakan bahasa tulis sebagai medianya (Suparno dan Yunus, 2003). Pesan adalah isi atau muatan yang terkandung dalam suatu tulisan, sedangkan tulisan merupakan simbol atau lambang bahasa yang dapat dilihat dan disepakati pemakainya. Dalam komunikasi tulis, paling tidak terdapat empat unsur yang terlibat, yakni penulis sebagai penyampai pesan, isi tulisan, saluran atau media yang berupa tulisan, dan pembaca sebagai penerima pesan.

Selama ini, pembelajaran menulis lebih ditekankan pada hasil yang berupa tulisan, tidak pada apa yang seharusnya dikerjakan siswa ketika menulis. Siswa langsung melakukan praktik menulis tanpa belajar bagaimana caranya menulis. Guru meminta siswa untuk menulis sesuai dengan kompetensi dasar dalam kurikulum. Setelah selesai, tulisan siswa dikumpulkan, dikoreksi, dan dinilai oleh guru. Kegiatan ini terus-menerus dilakukan yang mengakibatkan siswa merasa jenuh dan tidak bergairah dalam mengikuti pembelajaran menulis. Akibatnya, keterampilan menulis siswa sangat rendah.

Salah satu upaya untuk meningkatkan kualitas pembelajaran menulis adalah dengan melakukan inovasi model pembelajaran melalui penerapan pendekatan proses genre. Pendekatan ini merupakan perpaduan antara pendekatan proses dan pendekatan genre (Nordin \& Mohammad, 2006; Lee, Goh, Chan, \& Yang, 2007).

Untuk melakukan inovasi model pembelajaran menulis melalui penerapan pendekatan proses genre itu, harus dikembangkan perangkat pembelajarannya. Perangkat pembelajaran itu mencakup silabus, rencana pelaksanaan pembelajaran, materi ajar, instrumen evaluasi, dan panduan pembelajaran. Perangkat pembelajaran ini perlu dikembangkan berdasarkan pertimbangan bahwa (1) guru memang memerlukan perangkat pembelajaran yang inovatif, dan (2) perangkat pembelajaran itu menjadi panduan guru dalam melaksanakan kegiatan pembelajaran. 
Berdasarkan pertimbangan itulah, penelitian ini bertujuan untuk menghasilkan model perangkat pembelajaran menulis berdasarkan pendekatan proses genre bagi siswa SMP. Secara khusus, tujuan penelitian ini adalah: (1) menghasilkan silabus pembelajaran menulis berdasarkan pendekatan proses genre bagi siswa SMP, (2) menghasilkan rencana pelaksaaan pembelajaran (RPP) menulis berdasarkan pendekatan proses genre bagi siswa SMP, (3) menghasilkan materi pembelajaran menulis berdasarkan pendekatan proses genre bagi siswa SMP, (4) menghasilkan instrumen evaluasi pembelajaran menulis berdasarkan pendekatan proses genre bagi siswa SMP, dan (5) menghasilkan panduan pembelajaran menulis berdasarkan pendekatan proses genre bagi siswa SMP.

Menurut Badger \& White (2000), pada dasarnya terdapat tiga pendekatan utama dalam pembelajaran menulis, yakni (1) pendekatan produk, (2) pendekatan proses, dan (3) pendekatan genre. Akan tetapi, karena setiap pendekatan tersebut memiliki keunggulan dan kelemahan masing-masing, ketiganya dianggap saling melengkapi sehingga disarankan adanya pendekatan baru, yang disebut pendekatan proses genre (Badger \& White, 2000; Kim \& Kim, 2005; Xu, 2005; Kaur \& Chun, 2005; Kim, 2007; Yan, 2005; Gao, 2007; dan Lee, Goh, Chan, \& Yang, 2007).

Menurut Badger \& White (2000), dalam pembelajaran menulis pada dasarnya harus dipertimbangkan bahwa menulis meliputi pengetahuan tentang bahasa (seperti yang ditekankan dalam pembelajaran menulis dengan pendekatan produk dan pendekatan genre), pengetahuan tentang konteks tempat tulisan itu digunakan khususnya tentang tujuan (seperti dalam pendekatan genre), dan keterampilan menggunakan bahasa (seperti dalam pendekatan proses), serta peristiwa pengembangan menulis melalui pemberdayaan potensi siswa (seperti dalam pendekatan proses), dan melalui penyediaan input sebagai sumber respon siswa (seperti dalam pendekatan produk dan pendekatan genre). Pendekatan pembelajaran menulis yang memperhatikan berbagai pertimbangan tersebut disebut pendekatan proses genre (Badger \& White, 2000).

Menurut Lee, Goh, Chan, \& Yang (2007), pendekatan proses genre dalam pembelajaran menulis merupakan perpaduan antara pendekatan proses dan pendekatan genre. Perencanaan, penulisan draf, konferensi, pengeditan, dan revisi teman sejawat merupakan komponen dari pendekatan proses, sedangkan pemahaman dan pertimbangan terhadap tujuan, pembaca, dan konteks merupakan komponen dari pendekatan genre (Nordin \& Mohammad, 2006).

Pendekatan proses genre memandang pentingnya pengembangtan tulisan melalui input yang relevan dan terkait dengan konteks, tujuan, dan audien (pembaca). Selain itu, pendekatan ini juga menekankan dan mendorong siswa untuk menggunakan gambaran linguistik dan struktur yang dominan pada genre tulisan tertentu. Dengan kata lain, pendekatan proses genre ini memungkinkan siswa untuk mempelajari bagaimana hubungan antara tujuan dan bentuk genre tulisan tertentu seperti yang mereka susun dalam proses yang berulang mulai dari pramenulis, penulisan draf, revisi, dan penyuntingan (Yan, 2005).

Menurut Badger \& White (2000), Xu, (2005), Kaur \& Chun (2005), Yan (2005), Kim (2007), Gao (2007), dan Lee, Goh, Chan, \& Yang (2007), pendekatan proses genre mencakup penciptaan kondisi ketika siswa dibantu untuk mengidentifikasi tujuan menulis mempertimbangkan bentuk, gaya, dan konteks suatu teks tulisan yang akan disusun. Teks tulisan dengan genre tertentu dipilih dan disajikan oleh guru yang kemudian akan mendorong siswa untuk menganalisis genre tersebut. Aktivitas pembelajaran dengan memper-

Model Perangkat Pembelajaran Menulis Berdasarkan Pendekatan Proses Genre ... 
hatikan aspek kebahasaan, yakni pilihan kata dan ketepatan tata bahasa, mungkin harus dilaksanakan. Selanjutnya, dengan bantuan kerangka tulisan yang berupa diagram atau peta konsep, siswa dapat merencanakan dan menyusun gagasan sebelum menulisan draf pertama dan merevisinya sesuai dengan tujuan dan pembaca nyata yang dikehendaki. Aspek kolaboratif dalam proses menulis sangat dipentingkan sebagaimana halnya dalam pendekatan proses yang berpusat pada siswa.

Lee, Goh, Chan, \& Yang (2007) menawarkan suatu model pembelajaran menulis berdasarkan pendekatan proses genre dengan delapan tahapan kegiatan pembelajaran. Kedelapan tahapan itu adalah (1) mengenal teks, (2) memahami bahasa teks, (3) berlatih menganalisis teks, (4) merefleksi, (5) mengembangkan ide atau bahan, (6) menyusun kerangka tulisan, (7) menulisan draf, dan (8) merevisi.

Pertama, siswa diperkenalkan dengan genre tulisan yang akan disusun. Melalui pemodelan genre tulisan yang disajikan, siswa dapat mempelajari struktur organisasi, karakteristik, dan konteks sosial penggunaan genre tulisan tersebut.

Kedua, siswa diperkenalkan dengan struktur kebahasaan dan atau kaidah penulisan yang biasa digunakan dalam genre tulisan tertentu. Aspek kebahasaan itu antara lain ragam bahasa yang digunakan, paragraf, kalimat, dan kosa kata serta ejaan dan tata tulis yang biasa digunakan dalam genre tulisan tertentu.

Ketiga, siswa berlatih untuk menganalisis teks. Pada kegiatan analisis teks ini siswa mengamati dan mengidentifikasi bagaimana penulis menyusun ide dan argumen sebagai kerangka dasar yang terdapat di dalam genre tulisan.

Keempat, siswa diminta untuk merefleksikan apa yang telah dipelajari tentang genre tulisan tertentu sebelum melaksanakan tugas menulis. Kegiatan ini membantu siswa dalam memikirkan pemahaman terhadap apa yang telah dipelajari. Hal itu juga membantu siswa untuk mengidentifikasi jurang pemisah atas konsep yang belum dipahami oleh siswa.

Kelima, siswa mengembangkan ide secara individu atau berkelompok untuk menggali, mengembangkan, dan mengumpulkan ide dan bahan tulisan yang akan disusun. Kegiatan pengembangan ide dapat dilakukan melalui kegiatan curah pendapat (brainstorming). Kegiatan curah pendapat dapat dilakukan melalui berbagai cara seperti menulis kata atau frasa kunci di papan tulis dan kemudian mebahasnya secara bergiliran, atau berdiskusi mengenai suatu topik tertentu yang sedang ramai dibicarakan dalam kehidupan sehari-hari. Selain itu, pada tahap pengembangan ide ini siswa dapat melakukan kegiatan lain untuk berusaha mencari dan mengembangkan idea atau bahan seperti mengamati, membaca, meneliti, atau melakukan wawancara. Keenam, siswa menyusun kerangka tulisan. Ada dua cara yang dapat dilakukan untuk menyusun kerangka tulisan, yakni dalam bentuk kerangka linier, dan atau menggambarkannya dalam peta konsep. Penyusunan kerangka tulisan ini sangat diperlukan terutama dalam rangka menata ide-ide yang akan ditulis.

Ketujuh, berdasarkan kerangka yang telah dibuat sebelumnya, siswa mulai menulis draf pertama mereka. Fokus utama kegiatan siswa pada tahapan ini adalah menuangkan ide, gagasan, atau pikiran ke dalam tulisan sesuai dengan bahan yang dikumpulkan. Oleh karena itu, jika siswa merasa kehabisan ide atau bahan, siswa dapat kembali mencari dan menemukan bahan tersebut.

Kedelapan, melalui kegiatan merevisi, siswa memeriksa atau meninjau hasil tulisannya. Ada berbagai langkah yang dapat dilakukan untuk memeriksa tulisan seperti membaca ulang dan memberi catatan tertentu, meminta teman untuk memeriksa tulisan, atau mengikuti konferensi dengan guru sebelum membuat 
perbaikan yang diperlukan. Setelah dilakukan pemeriksaan, barulah siswa merevisi tulisan baik yang mencakup aspek isi maupun aspek kebahasaan dan tata tulis. Setelah kegiatan merevisi selesai, siswa kemudian mempublikasikan hasil tulisannya kepada orang lain dalam bentuk pembacaan di dalam kelas, pemajangan pada papan pajangan kelas atau majalag dinding, penerbitan pada majalah sekolah, atau pembuatan antologi tulisan hasil karya siswa.

\section{METODE PENELITIAN}

Model desain penelitian pengembangan ini adalah Recursive Reflective Design and Development (R2D2) yang dikembangkan oleh Willis (1995) berdasarkan pandangan konstruktivisme. Model ini dipilih dengan pertimbangan bahwa model ini bersifat reflektif, rekursif, kolaboratif, dan berkembang sehingga memberi kesempatan peneliti dan pihak-pihak yang terkait untuk mengembangkan produk perangkat pembelajaran yang sesuai dengan kebutuhan secara terus-menerus sampai ditemukan produk yang dianggap paling tepat, efektif, dan efisien.

Prosedur penelitian pengembangan ini terdiri dari tiga tahap, yakni (1) pendefinisian, (2) perencanaan dan pengembangan, dan (3) penyebarluasan. Aktivitas pendefinisian difokuskan pada (a) menciptakan kerja sama tim, (b) solusi problem progresif, dan (c) pemahaman masalah secara kontekstual. Aktivitas perencanaan dan pengembangan difokuskan pada (a) mempelajari konteks pembelajaran, (b) memilih format dan media, (c) menentukan strategi evaluasi, dan (d) mendesain produk dan pengembangannya. Aktivitas penyebarluasan difokuskan pada (a) evaluasi otentik, dan (b) penyusunan paket akhir produk sesuai dengan konteks.

Untuk mengetahui kelayakan produk yang dikembangkan, telah dilakukan uji coba dan uji lapangan. Uji coba pengembangan produk terdiri dari uji ahli, uji praktisi, dan uji pengguna. Berdasarkan hasil uji coba tersebut dilakukan revisi terhadap produk yang dikembangkan. Sementara itu, uji lapangan dilakukan untuk mengetahui efektivitas produk dalam bentuk eksperimen semu dengan rancangan pretest and post test design dengan satu kelas subjek siswa sebagai kelompok kontrol dan satu kelas siswa sebagai kelompok eksperimen. Data yang diperoleh, yakni kemampuan menulis awal dan akhir pada kelas kontrol dan ekperimen dianalisis dengan menggunakan teknik analisis uji t.

Subjek uji coba pengembangan produk penelitian ini adalah ahli metodologi pembelajaran bahasa Indonesia, ahli teknologi pembelajaran, guru-guru bahasa Indonesia di SMP Negeri 1 Kalasan, dan guruguru pengurus Musyawarah Guru Mata Pelajaran (MGMP) Bahasa Indonesia Kabupaten Sleman, dan siswa kelas VIII SMP Negeri 1 Kalasan Kabupaten Sleman.

Data penelitian ini terdiri atas data kualitatif dan kuantitatif. Data kualitatif berupa kritik, saran, dan komentar yang ditulis pada berkas model atau lembar instrumen penilaian, dan atau disampaikan secara lisan dalam kegiatan diskusi. Data tersebut digunakan untuk menganalisis, merevisi, dan menyempurnakan model perangkat pembelajaran. Data kuantitatif berupa nilai kemampuan menulis siswa yang diperoleh berdasarkan pretes dan postes pada kelompok kontrol yang diberi perlakuan stategi konvensional dan kelompok eksperimen yang diberi perlakuan pendekatan proses genre. Data tersebut digunakan untuk mengetahui efektivitas produk model perangkat pembelajaran menulis.

Teknik analisis data yang digunakan dalam penelitian ini adalah analisis kualitatif dan analisis statistik deskriptif dan uji-t. Analisis kualitatif dengan teknik analisis domain dengan prinsip kritis dan reflektif digunakan untuk menganalisis data kualitatif yang berupa hasil penilaian numerik, komentar, kritik, dan saran

Model Perangkat Pembelajaran Menulis Berdasarkan Pendekatan Proses Genre ... 
yang diperoleh dari angket dan wawancara dalam proses uji ahli dan praktisi, uji kelompok kecil, dan uji kelompok besar. Analisis statistik uji t dengan program SPSS 15.0 for Windows digunakan untuk menganalisis data kuantitatif yang berupa skor nilai hasil pembelajaran menulis. Uji-t digunakan untuk menentukan efektivitas penggunaan produk pengembangan.

\section{HASIL DAN PEMBAHASAN}

Hasil penelitian ini terdiri dari lima model perangkat pembelajaran menulis, yaitu (1) model silabus pembelajaran menulis berdasarkan pendekatan proses genre, (2) model RPP menulis berdasarkan pendekatan proses genre, (3) model materi pembelajaran menulis berdasarkan pendekatan proses genre, (4) model instrumen evaluasi pembelajaran menulis berdasarkan pendekatan proses genre, dan (5) model panduan pembelajaran menulis berdasarkan pendekatan proses genre. Model silabus, RPP, materi pembelajaran, dan instrumen evaluasi pembelajaran menulis terdiri atas delapan macam, yaitu model untuk (a) pembelajaran menulis laporan, (b) pembelajaran menulis surat dinas, (c) pembelajaran menulis petunjuk, (d) pembelajaran menulis naskah drama, (e) pembelajaran menulis rangkuman, (f) pembelajaran menulis teks berita, $(\mathrm{g})$ pembelajaran menulis slogan/poster, dan (h) pembelajaran menulis puisi bebas. Model panduan pembelajaran menulis berdasarkan pendekatan proses genre terdiri dari satu model panduan umum pembelajaran dan delapan model panduan khusus, yaitu panduan khusus pembelajaran (a) menulis laporan, (b) menulis surat dinas, (c) menulis petunjuk, (d) menulis naskah drama, (e) menulis rangkuman, (f) menulis teks berita, (g) menulis slogan/poster, dan (h) menulis puisi bebas. Kelima model perangkat pembelajaran itu dikembangkan berdasarkan sintaks pembelajaran menulis berdasarkan pendekatan proses genre, yakni (1) mengenal teks, (2) memahami bahasa teks, (3) berlatih menganalisis teks, (4) merefleksi, (5) mengembangkan ide atau bahan, (6) menyusun kerangka tulisan, (7) menulisan draf, dan (8) merevisi, dan diakhiri dengan kegiatan (9) melakukan evaluasi diri dan (10) melakukan kegiatan tindak lanjut. Sintaks model pembelajaran menulis berdasarkan pendekatan proses genre itu dapat dijelaskan seperti gambar 1 .

Kelima model perangkat pembelajaran kemudian dilakukan uji coba dan uji lapangan. Uji coba yang dilakukan meliputi uji ahli, uji praktisi, dan uji pengguna. Rangkaian uji coba dilakukan untuk mengetahui kelayakan produk yang dikembangkan, sedangkan uji lapangan dilakukan untuk mengetahui keefektifan produk yang dikembangkan.

Hasil uji ahli menunjukkan bahwa berdasarkan data numerik kelima model perangkat pembelajaran menulis sudah layak untuk diterapkan dalam pembelajaran di kelas. Namun demikian, berdasarkan data kualitatif dilakukan revisi terhadap produk perangkat pembelajaran. Revisi terhadap materi ajar menyangkut penambahan materi dan penjelasan, serta perbaikan tata tulis dan ejaan. Revisi terhadap panduan pembelajaran dilakukan dengan cara membagi panduan itu menjadi dua yakni panduan umum dan panduan khusus. Sementara itu, revisi terhadap instrumen evaluasi dilakukan terhadap penambahan deskriptor dan indikator pada setiap aspek yang dinilai.

Hasil uji praktisi menunjukkan bahwa berdasarkan data numerik kelima model sudah layak untuk diterapkan dalam pembelajaran di kelas. Namun demikian, berdasarkan data kualitatif perlu dilakukan revisi terutama terhadap produk materi pembelajaran dan panduan pembelajaran. Revisi terhadap materi ajar menyangkut perbaikan tata tulis dan ejaan. Revisi terhadap panduan pembelajaran menyangkut perbaikan tata tulis dan ejaan.

Hasil uji pengguna menunjukkan bahwa berdasarkan data numerik kelima 


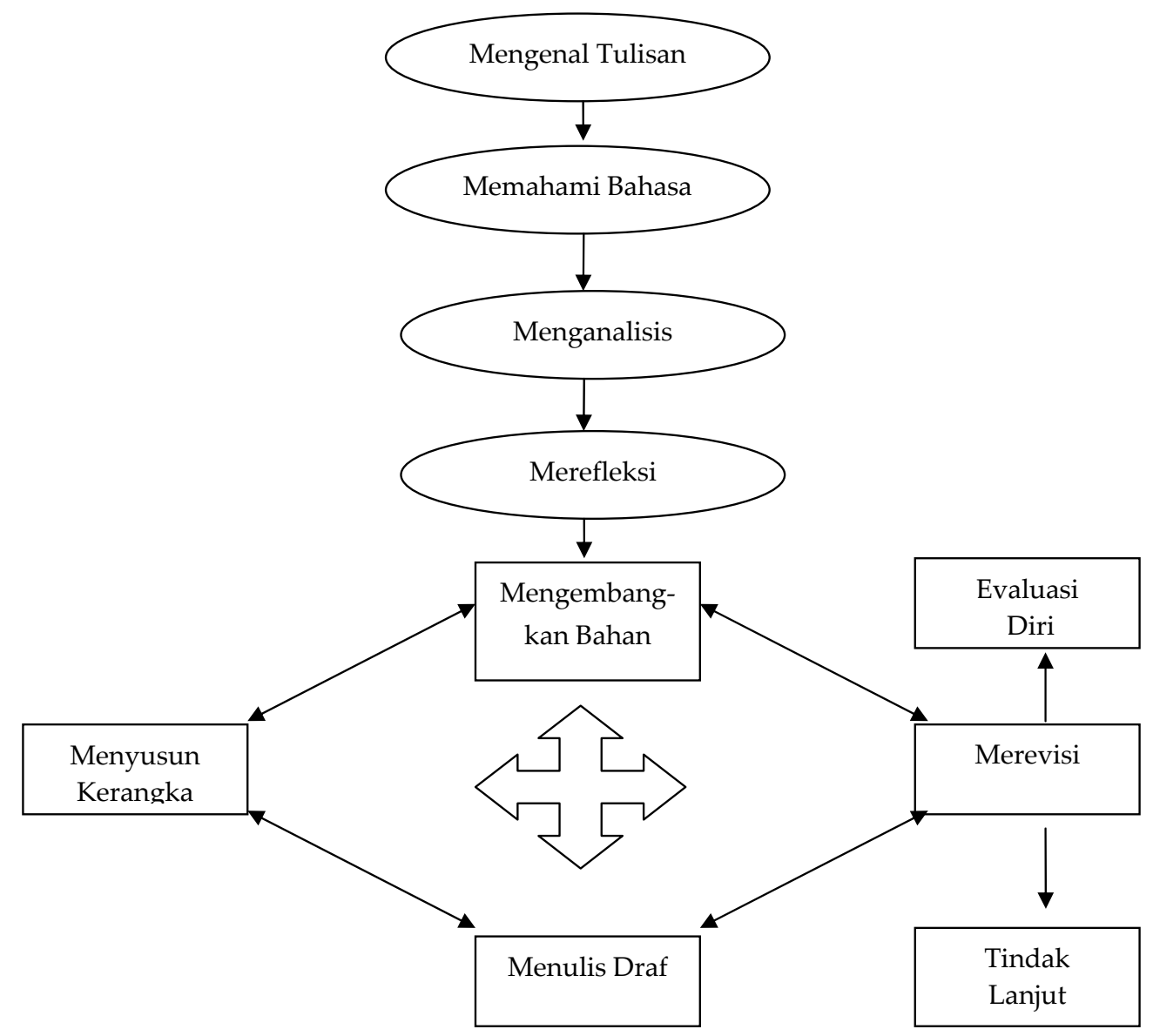

Gambar 1. Model Pembelajaran Menulis Berdasarkan Pendekatan Proses Genre

model sudah layak untuk diterapkan dalam pembelajaran di kelas. Namun demikian, berdasarkan data kualitatif perlu dilakukan revisi terutama terhadap produk materi pembelajaran. Revisi terhadap materi ajar menyangkut perbaikan tata tulis dan ejaan.

Setelah mengalami revisi berdasarkan hasil uji ahli, uji praktisi, dan uji pengguna, telah dihasilkan lima model perangkat pembelajaran menulis, yaitu (1) model silabus pembelajaran menulis berdasarkan pendekatan proses genre, (2) model RPP menulis berdasarkan pendekatan proses genre, (3) model materi pembelajaran menulis berdasarkan pendekatan proses genre, (4) model instrumen evaluasi pembelajaran menulis berdasarkan pendekatan proses genre, dan (5) model panduan pembelajaran menulis berdasarkan pendekatan proses genre. Kelima model perangkat pembelajaran itu kemudian dilakukan uji lapangan untuk mengetahui efektivitas produk.

Berdasarkan hasil uji lapangan diketahui hasil uji t pretes dan postes kemampuan menulis kelompok eksperimen sebagai berikut: (1) menulis laporan memperoleh harga $t=-26,796(p=0,000)$, (2) menulis surat dinas memperoleh harga $t=-15,000(p=0,000)$, (3) menulis petunjuk memperoleh harga t sebesar $=-12,405$ $(\mathrm{p}=0,000),(4)$ menulis naskah drama memperoleh harga t sebesar $-26,470(\mathrm{p}=$ $0,000)$, (5) menulis rangkuman memperoleh harga t sebesar $-17,858(p=0,000)$, (6) menulis teks berita memperoleh harga $\mathrm{t}$ sebesar $=-25,628(p=0,000),(7)$ menulis slogan/poster memperoleh harga sebesar $=-6,720(\mathrm{p}=0,000)$, dan (8) menulis puisi 
memperoleh harga $\mathrm{t}$ sebesar $-3,478(\mathrm{p}=$ $0,001)$. Hal ini mengandung arti bahwa terdapat perbedaan skor pretes dan postes kemampuan menulis yang signifikan. Oleh karena itu, dapat dinyatakan bahwa model perangkat pembelajaran menulis berdasarkan pendekatan proses genre tersebut terbukti efektif terhadap peningkatan kemampuan menulis pada siswa kelas VIII SMP Negeri 1 Kalasan Kabupaten Sleman.

Secara terotik kelima model perangkat pembelajaran menulis itu dikembangkan berdasarkan pendekatan proses genre. Gagasan menggunakan pendekatan proses genre dalam pembelajaran menulis ini didasari oleh pandangan Badger \& White (2000), bahwa penggunaan pendekatan pembelajaran menulis yang berbasis produk, proses, dan genre secara sendirisendiri itu memiliki kelemahan tetapi jika digabungkan akan menjadi suatu model pembelajaran yang baik. Pandangan ini kemudian diikuti oleh para ahli yang lain seperti Kim \& Kim (2005), Xu (2005), Kaur \& Chun (2005), Kim (2007), Yan (2005), Gao (2007), dan Lee, Goh, Chan, \& Yang (2007).

Langkah-langkah kegiatan pembelajaran yang dikembangkan dan mendasari kelima model perangkat pembelajaran menulis tersebut juga menunjukkan adanya partisipasi, kerja kolaboratif, dan keaktifan siswa di dalam kelas. Partisipasi individu siswa dalam kegiatan pembelajaran sangat diperlukan sesuai dengan pendapat Piaget (1950) yang menekankan keaktifan individu dalam membentuk pengetahuan sehingga ia menemukan makna belajar. Kerja kolaboratif siswa dalam kegiatan pembelajaran sesuai dengan pendapat Vygotksy (1978) tentang pentingnya peran guru dan teman lain dalam belajar. Selain itu, keaktifan siswa dalam pembelajaran yang dikembangkan dalam silabus sesuai dengan pandangan von Glasersfeld (1995) yang menekankan bahwa dalam kegiatan pembelajaran siswa hendaknya aktif belajar untuk mengkonstruksi pengetahuan berdasarkan pengalaman belajar sendiri. Di sisi lain, kegiatan kolaboratif dan reflektif yang terdapat dalam silabus pembelajaran tersebut juga menunjukkan adanya rasa tanggung jawab siswa terhadap kegiatan pembelajaran seperti yang disarankan oleh Conzemius \& O'Neil (2001). Dengan demikian, dapat dinyatakan bahwa langkah-langkah kegiatan pembelajaran yang dikembangkan dalam model perangkat pembelajaran menulis berdasarkan pendekatan proses genre ini sesuai dengan pandangan konstruktivistik.

Akhirnya dapat dinyatakan bahwa berdasarkan analisis data kualitatif, kelima model perangkat pembelajaran menulis tersebut termasuk ke dalam kategori sangat layak. Berdasarkan analisis data kuantitatif diketahui bahwa terdapat perbedaan yang signifikan skor pretes dan postes kemampuan menulis berdasarkan pendekatan proses genre pada siswa kelas VIII SMP Negeri 1 Kalasan Kabupaten Sleman sehingga dapat dinyatakan bahwa model perangkat pembelajaran tersebut terbukti efektif untuk meningkatkan kemampuan siswa.

\section{SIMPULAN}

Berdasarkan hasil penelitian dan pembahasan dapat disimpulkan bahwa (1) kelima model perangkat pembelajaran menulis berdasarkan pendekatan proses genre yang dikembangkan memiliki tingkat kelayakan yang sangat layak dan (2) model perangkat pembelajaran menulis berdasarkan pendekatan proses genre tersebut terbukti efektif terhadap peningkatan kemampuan menulis pada siswa kelas VIII SMP Negeri 1 Kalasan Kabupaten Sleman.

Sehubungan dengan itu, penulis materi ajar, dan pengembang kurikulum disarankan memanfaatkan produk penelitian ini sebagai salah satu alternatif dalam upaya meningkatkan kualitas pembelajaran menulis di sekolah. Selain itu, disarankan agar dilakukan sosial- 
isasi produk dan konsep teoritik, serta pengembangan produk yang lebih luas cakupannya.

\section{UCAPAN TERIMA KASIH}

Artikel ini disarikan dari hasil penelitian disertasi pada Program Pascasarjana Universitas Negeri Malang dan dibiayai oleh dana penelitian hibah doktor DP2M Direktorat Pendidikan Tinggi Kementrian Pendidikan Nasional tahun 2010. Ucapan terima kasih saya sampaikan kepada Prof. Dr. Suparno (Promotor), Prof. Dr. Ah. Rofi'uddin, M. Pd. (Kopromotor), dan Dr. Nurhadi, M. Pd. (Kopromotor) yang telah membimbing dan membantu terhadap penelitian ini.

\section{DAFTAR PUSTAKA}

Alwasilah, Ch. 2005. Peningkatan Penggunaan Bahasa Ilmiah dalam Membangun Budaya Menulis. Dalam (Wiedarti, Editor.), Мепијu Budaya Benulis, suatu Bunga Rampai (hlm. 3-7). Yogyakarta: Tiara Wacana.

Anshori, D. S. 2003. Membaca dan Menulis: Tentang Budaya yang Gagap. Dalam (Harras, Kurniawan, dan Anshori, Editor), Mendamba Indonesia yang literat, Esai-esai Bahasa, Sastra, dan Pengajarannya. Bandung: FPBS Universitas Pendidikan Indonesia.

Badger, R. \& White, G. 2000. A Process Genre Approach to Teaching Writing. English Language Teaching Journal, Vol. 54/2 (April 2000), 153-160.

Baer, J., Baldi, S., Ayotte, K. \& Green, P. 2007. The Reading Literacy of U.S. Fourth-grade Students in an International Context: Results from the 2001 and 2006 Progress in International Reading Literacy Study (PIRLS). Washington, DC: National Center for Education Statistics, Institute of Education Sciences, U.S. Department of Education.

Barton, D., Hamilton, M. \& Ivanic, R. 2000. Situated Literacy, Reading and Writing in Context. London: Rotlegde.
Conzemius, A., \& O’Neill, J. 2001. Buliding Shared Responsibility for Students Learning. Alexandra, VA: Association for Supervision and Curriculum Development.

Elly, W. B. 1992. How in the World Do Students Read, IEA Study of Reading Literacy. Hamburg: The International Association for the Evaluation of Education Achivement.

Gao, J. 2007. Teaching Writing in Chinese Universities: Finding an Eclectic Approach. Asian EFL Journal, May 2007, Volume 20

Hyland, K. 2007. Second Language Writing. 4th Printing. Cambridge: Cambridge Univseristy Press.

Kaur, S. \& Chun, P. S. 2005. Towards a Process-Genre Based Approach in the Leaching of Writing for Business English. English for Specific Purposes World, 2005, 3 (11), (4).

Kim, Y. \& Kim, J. 2005. Teaching Korean University Writing Class: Balancing the Process and Genre Approach. Asian EFL Journal, 2005,7 (2), 1-15.

Kim, M. S. 2007. Genre-Based Approach to Teaching Writing. Teaching English as Second Language, 2007, 33-39.

Knapp, P. \& Watkins, M. 2005. Genre, Text, Grammar. Sydney, NSW: University of New South Wales Press Ltd.

Lee, K.C., Goh, H., Chan, J. \& Yang, Y. 2007. Effective College Writing: A Process Eenre Approach. Singapore: McgrawHill.

Nordin, S. Md. \& Mohammad, N. 2006. The Best of Two Approach: Process Genre-Based Approach to Teaching Writing, The English Teacher, 2006, Vol. XXXV, 75-85.

Nunan, D. 1999. Second Language Teaching and Learning. Boston: Heinle \& Heinle Publishers.

Piaget, J. 1950. The Psychology of Inteliigence. London: Routlegde and Keagen Paul.

Model Perangkat Pembelajaran Menulis Berdasarkan Pendekatan Proses Genre ... 
Putra, E. P. 2008. Gerakan Menggiatkan Budaya Literal. Media Indonesia, $31 \mathrm{Mei}$ 2008, hlm. 6.

Sibarani, B. 2007. Penerapan Pproses Kognitif dan Terapi Cognitive Blocking dalam Peningkatan Kualitas Pembelajaran Menulis. Diksi, Volume 14, Nomor 2, Juli 2007, 78-102.

Slamet, St. Y. 2007. Dasar-dasar Keterampilan Berbahasa Indonesia. Surakarta: LPP UNS dan UNS Press.

Suparno \& Yunus, M. 2003. Keterampilan Dasar Menulis. Jakarta: Universitas Terbuka.

Supriyoko. 2004. Kebangkitan Pendidikan Kita. Kedaulatan Rakyat, 26 Mei 2004, hlm. 12.

Vygotsky, L. S. 1978. Mind in Society. Cambridge: Harvard University Press.
Von Glasersfeld, E. 1995. Radical Constructivism: A Way of Knowing and Learning. London: Routledge.

Willis, J. 1995. A Recursive, Reflective Instructional Design Model Based on Constructivist-Interpretative Theory. Educational Technology, 1995, 35, (6), 5-23.

Xu, X. 2005. An Integrated Approach to the Teaching of English Writing. Sino-US English Teaching, (Online), Dec. 2005, Volume 2, No.12, (http://www.linguist. org.cn/doc/su200512/su20051209.pdf diakses 12 Mei 2008).

Yan, G. 2005. A Process Genre Model for Teaching Writing. English Teaching Forum, 2005, 43 (3), 18-22. 